\title{
Editorial
}

\section{Prospecção Tecnológica, Propriedade Intelectual e Inovação}

A prospecção tecnológica é o primeiro passo na longa jornada da estratégia de agregação de valor a novos conhecimentos e a novas tecnologias, por meio da proteção jurídica da propriedade intelectual, visando a sua conversão em inovação. Isso porque é por meio da prospecção em bases de dados de propriedade intelectual que se consegue verificar se o objeto inovador atende ao requisito novidade, fundamental para a proteção, sobretudo por meio de patente de invenção. Esta tem por objetivo dar à inovação baseada no objeto da proteção ou que o contenha a necessária segurança jurídica, de modo que o empreendedor, que aceita assumir o risco de investir para introduzir essa novidade no mercado, obtenha a vantagem de sua exclusividade por um tempo determinado.

Sabe-se que o longo caminho a ser percorrido pela materialização de uma ideia inovadora, para ser convertida em inovação, começa com sua revelação, seguida de sua prospecção, que precisar ter preenchidos os requisitos indispensáveis à proteção da propriedade intelectual, e desta receber valor transacional, como um bem intangível a ser objeto de investimento de capital financeiro e tecnológico, a fim de chegar ao mercado produzindo riqueza e bem-estar, seja por meio do aumento da produtividade e da competitividade, seja do aumento da qualidade de vida, em síntese, em benefício da sociedade.

Há, portanto, uma lógica a ser seguida na implementação de uma estratégica destinada a incrementar a inovação que compreende diversos atores em interação e cuja colaboração é fundamental para o alcance desse objetivo, porque a pesquisa de qualidade e a criatividade nem sempre pertencem ao mesmo grupo que empreende e leva a novidade ao mercado. Por essa razão, a comunicação e a colaboração desses atores são fundamentais para o sucesso do empreendimento, que inclui múltiplas permutas, indispensável apoio financeiro e incentivos de diversas naturezas.

Como dizia Peter Drucker, a maioria das inovações resulta da busca consciente e intencional de oportunidades, e a prospecção tecnológica é fundamental não só para verificar o estado da técnica mas também para indicar territórios onde o objeto da 
pesquisa está sendo encontrado, permitindo o mapeamento de eventuais parceiros ou concorrentes, bem como caminhos alternativos que possam garantir a exclusividade necessária à introdução de uma inovação no mercado.

Shirley Coutinho 